\title{
Presence of Illicit Drugs in the Sarno River (Campania Region, Italy)
}

\author{
Massimo Maddaloni1 ${ }^{*}$, Sara Castiglioni2, Ettore Zuccato², Flaminia Gay1, Anna Capaldo1, \\ Vincenza Laforgia1, Salvatore Valiante', Maria De Falco ${ }^{1}$, Marco Guida1 \\ ${ }^{1}$ Department of Biology University, Federico II, Naples, Italy \\ ${ }^{2}$ Department of Environmental Health Sciences, Mario Negri Institute for Pharmacological Research, \\ Milan, Italy \\ Email: massimo.maddaloni@unina.it, ${ }^{*}$ madmax09@libero.it
}

Received 2 April 2014; revised 24 May 2014; accepted 24 June 2014

Copyright (C) 2014 by authors and Scientific Research Publishing Inc.

This work is licensed under the Creative Commons Attribution International License (CC BY).

http://creativecommons.org/licenses/by/4.0/

(c) (i) Open Access

\section{Abstract}

The presence of illicit drugs and their metabolites in surface waters has to be considered a new type of hazard, still unknown, for both the human health and the aquatic ecosystem, due to the potent pharmacological activities of all the illicit drugs. Our research was aimed at evaluating the presence of illicit drugs in the Sarno River (Campania region, Italy), crossing a densely populated area, the basin of the Sarno River, one of the largest and most important economic areas in Campania region, famous for the presence of zones with high landscape-environmental value. The drugs selected for this study were the most used in Campania region. The presence of illicit drugs in surface water was analyzed by a selective multi-residue assay based on liquid chromatographytandem mass spectrometry. The analysis showed the presence of all the illicit drugs investigated: cocaine and its main metabolites (benzoylecgonine, nor-benzoylecgonine), morphine, THC-COOH and codeine; cocaine was the most abundant illicit drug. The presence of illicit drugs and their metabolites in the Sarno River suggests new potential risk for the basin's inhabitants, using water in the food chain, via field irrigation and animal feed, and for the health of the aquatic fauna.

\section{Keywords}

Campania Region, Cocaine Pollution, Environmental Illicit Drugs, Sarno River Pollution, Surface Water Pollution

\section{Introduction}

Recent studies showed the presence of illicit drugs, and their main metabolites, in surface waters [1]-[8]. Indeed, ${ }^{*}$ Corresponding author.

How to cite this paper: Maddaloni, M., Castiglioni, S., Zuccato, E., Gay, F., Capaldo, A., Laforgia, V., Valiante, S., De Falco, M. and Guida, M. (2014) Presence of Illicit Drugs in the Sarno River (Campania Region, Italy). Pharmacology \& Pharmacy, 5, 755-761. http://dx.doi.org/10.4236/pp.2014.57085 
the increasing use of illicit drugs in enormous quantities worldwide, causes these drugs, and their metabolites, to enter into the sewage networks, from which they are often only partially removed by sewage treatment plants [1] [3] [4] [9]. Therefore, drugs and their metabolites get to contaminate the receiving surface waters, and can now be considered common organic contaminants of the aquatic environment [8]. The presence of illicit drugs in surface waters has to be considered a new type of hazard, still unknown, for both the human health, through the food chain, and the aquatic ecosystem. Indeed, all the illicit drugs have potent pharmacological activities [10] [11] and are present in surface waters as complex mixtures. Therefore, though the environmental concentrations of illicit drugs are generally low [1]-[7], their presence in surface waters may lead to unforeseen pharmacological interactions and cause toxic effects to human health and aquatic organisms.

In Campania region (Figure 1(a)), the basin of the Sarno River (Figure 1(b)), with a population of over 1193.000 inhabitants, and an urban average density of about 1300 inhabitants per $\mathrm{km}^{2}$ [12], is one of the most densely populated regions of southern Italy. The basin is one of the largest and most important economic areas in Campania region, famous for the presence of zones with high landscape-environmental value, such as the Vesuvius National Park and the Picentini Mts. Regional Park, Sites of Community Importance like the Lattari
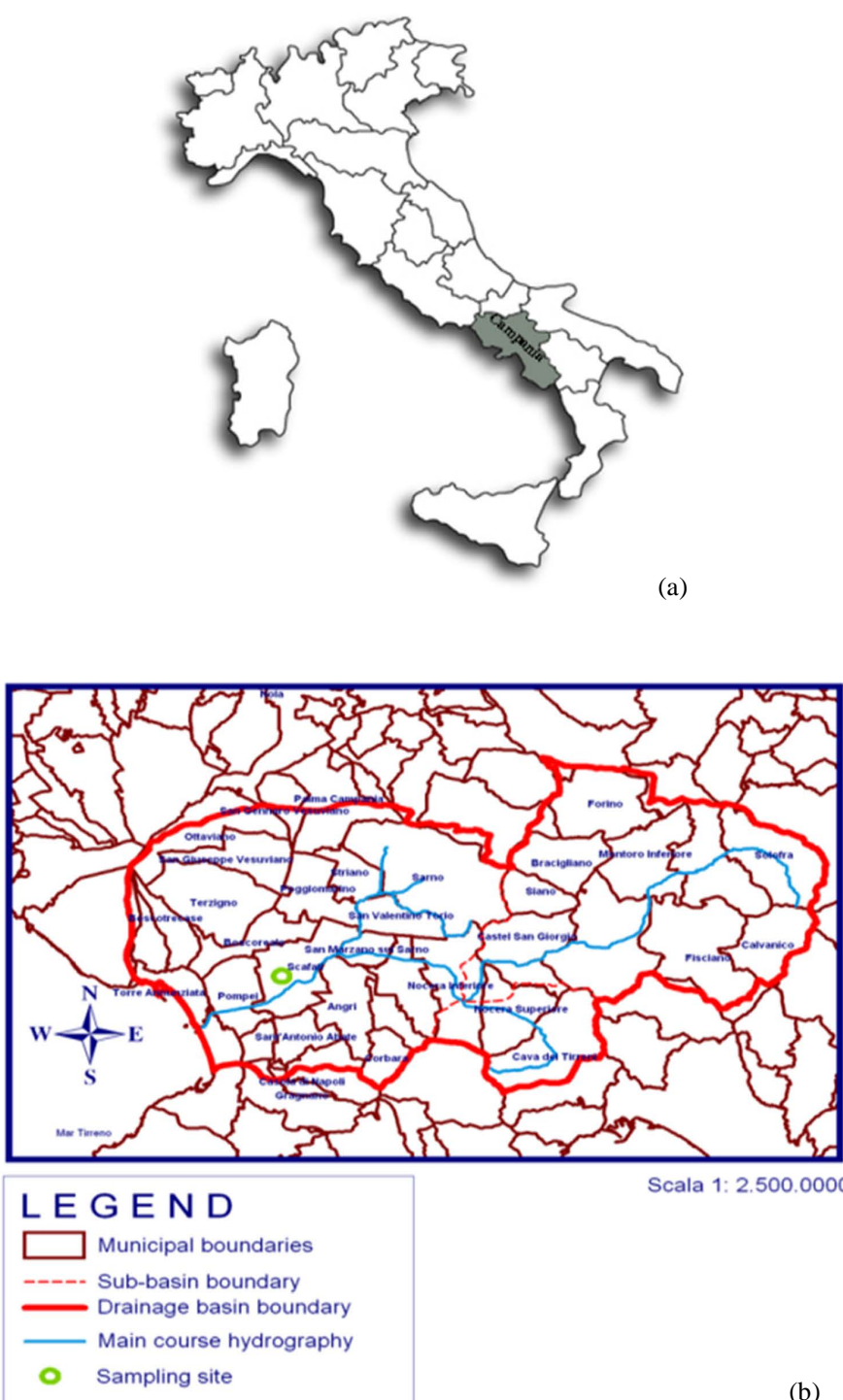

Scala 1: 2.500 .0000

(a)

Figure 1. Map of Italy showing: (a) The location of Campania region; (b) The basin of the Sarno River, showing the sampling site (circle) at Scafati, Salerno. 
Mts., Wildlife Reserves run by the WWF and other environmental associations, as well as important archaeological sites such as those of Pompeii, Herculaneum and Stabiae [12]. However, in 1992, the Council of Ministers proclaimed the Sarno basin an area at high risk of environmental crisis and proposed a reclamation project (Ministry Council's Decree 1992). Indeed, the Sarno River is a highly polluted river, affected by multiple pollution sources of domestic, agricultural and industrial origin [12]-[17]. Public health conditions are precarious as the basin's inhabitants consume low-quality water directly, but are also exposed to a cocktail of other pollutants due to the use of water in the food chain, via field irrigation and animal feed. Moreover, polluted basin waters flowing into the bay of Naples increase the contamination of sea water, damaging tourism and health and degrading local litoral quality [12]. Therefore, monitoring the pollution of the Sarno River water is very informative from a human health point of view, and may give information that could be used as a reference for future clean-up interventions.

Since recent data [18], indicated a wide illicit drug use in Campania region by its inhabitants, we hypothesized the presence of illicit drugs and their metabolites in the Sarno River, due to the high density of population of the area crossed by this river, including three provinces (Avellino, Naples and Salerno), and no fewer that thirty-nine municipalities. To verify our hypothesis, we selected the most used illicit drugs in Campania region [18]: cocaine and its main metabolites; morphine; a cannabis derivative, 11-nor-9-carboxy-delta9-tetrahydrocannabinol (THC-COOH), and an opioid pharmaceutical, codeine.

\section{Materials and Methods}

\subsection{Sample Collection}

The sampling site was the hydrographic station of Scafati (Naples, Campania region, Italy) (Figure 1(b)), along the Sarno River [12]. This site is situated afterwards the confluence of the common Channel in which the streams Cavaiola and Solofrana, the main affluents of the Sarno River, flow. Composite water sample (pool of six $500 \mathrm{ml}$ samples collected every 20 min during a period of $24 \mathrm{~h}$ ) by a portable automatic sampler (Sigma 900 Standard, Hack Company, USA) was frozen immediately after the collection and was stored $\mathrm{t}-20^{\circ} \mathrm{C}$, until analysis [2] [3].

\subsection{Chemicals and Materials}

Reference standard compounds were obtained for cocaine and its metabolites benzoylecgonine (BE), nor-benzoylecgonine and nor-cocaine; morphine; THC-COOH; codeine, as previously described [3] [4]. The following deuterated analogues were used as internal standards (IS): cocaine-D3, benzoylecgonine-D3, norcocaine-D3, morphine-D3, THC-COOH-D3, acquired from Cambridge Isotope Laboratories (Andover, MA). All solvents and reagents were analytical grade. HPLC grade Milli-Q water was obtained with a MILLI-RO PLUS 90 apparatus (Millipore, Molsheim, France). Cartridges for solidphase extraction were $3 \mathrm{~mL}$ disposable Oasis MCX (60 mg, Waters Corp., Milford, MA).

\subsection{Analytical Method}

Illicit drugs, codeine and their metabolites were analysed in surface water, as previously described [3] [4]. Briefly, water sample was solid-phase extracted by mixed reversed-phase, cation exchange cartridges (OasisMCX). Before extraction, sample (500 ml) was spiked with IS, and the $\mathrm{pH}$ was adjusted to 2.0 with $37 \% \mathrm{HCl}$. The Oasis MCX cartridges were conditioned before use by washing with $6 \mathrm{ml}$ methanol, $3 \mathrm{ml}$ MilliQ water and $3 \mathrm{ml}$ water acidified to $\mathrm{pH}$ 2. Sample was then passed through the cartridges under vacuum, at a flow rate of 10 $\mathrm{ml} / \mathrm{min}$. Cartridges were vacuum-dried for $5 \mathrm{~min}$ and eluted with $3 \mathrm{ml}$ of methanol and $3 \mathrm{ml}$ of a $2 \%$ ammonia solution in methanol. The eluates were pooled and dried under a nitrogen stream. Dried samples were redissolved in $200 \mathrm{ml}$ of MilliQ water, centrifuged, transferred into glass vials and analysed by high-pressure liquid chromatography-tandem mass spectrometry (HPLC-MS/MS) using an API 3000 triple quadrupole mass spectrometer, equipped with a turbo ion spray source (Applied Biosystems-Sciex, Thornhill, Ontario, Canada) and interfaced to LC Series 200 pumps and autosampler (Perkin-Elmer, Norwalk, CT). Drugs were analysed using an XTerra MS C18, $100 \times 2.1 \mathrm{~mm}, 3.5 \mu \mathrm{m}$ column (Waters Corp., Milford, MA), at a flow rate of $200 \mu \mathrm{l} / \mathrm{min}$. Typical chromatograms of the main substances in the Sarno River are provided in Figure 2. Information about the method performance in surface water and the instrumental repeatability and precision, the instrumental limits 


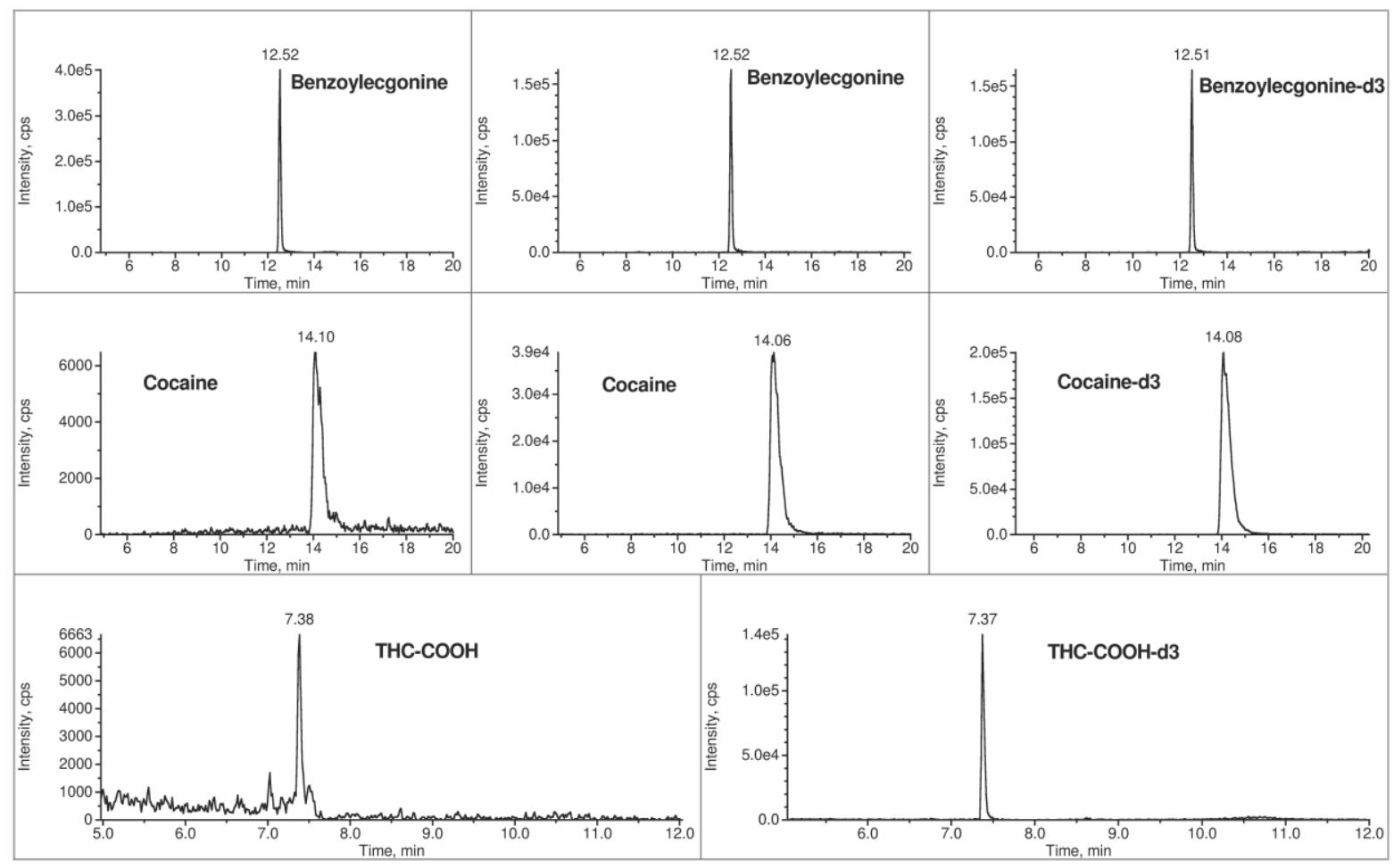

Figure 2. Typical HPLC chromatograms of benzoylecgonine, cocaine and THC-COOH and their correspondent labelled internal standards used for quantification.

of detection and quantification, and the linearity of the analytical response has been published elsewhere [3] [4].

\subsection{Statistical Analysis}

The concentrations of illicit drugs (cocaine, morphine, THC-COOH and Codeine) were tested together for significance using one-way analysis of variance (ANOVA), followed by Duncan's test for multigroup comparison and Student's $t$ test for between group comparison. The same type of test was applied to the cocaine metabolites. Differences were considered significant when $\mathrm{P}<0.05$.

\section{Results}

All the drugs selected were found in the Sarno River. Concentrations of cocaine and its metabolites, morphine, THC-COOH and codeine ranged from 1 to $91 \mathrm{ng} /$; cocaine concentration was significantly $(\mathrm{P}<0.001)$ higher than morphine, THC-COOH and codeine. Among the metabolites of cocaine, benzoylecgonine was the most abundant $(\mathrm{P}<0.001)$; nor-cocaine was undetectable (Figure 3).

\section{Discussion}

The present results show, for the first time, the presence of illicit drugs in the Sarno River: cocaine and some metabolites; morphine, a common metabolic residue of heroin, codeine and morphine itself; THC-COOH, the main active compound of cannabis; codeine, an opioid analgesic that can be metabolized and excreted as morphine [19] [20]. These results show therefore that also the Sarno River is exposed to the same type of illicit drug contamination as many others Italian and European rivers [1]-[7] and confirm that the illicit drugs can be considered common contaminants of the aquatic environment [3] [8].

Cocaine concentration was higher than morphine, THC-COOH and codeine, in agreement with data showing a higher use of this drug in Campania region, compared with other illicit drugs [18]. Among the metabolites of cocaine, BE, the major metabolite, was the most abundant in the Sarno River, as was found in other rivers [1]-[7]. 


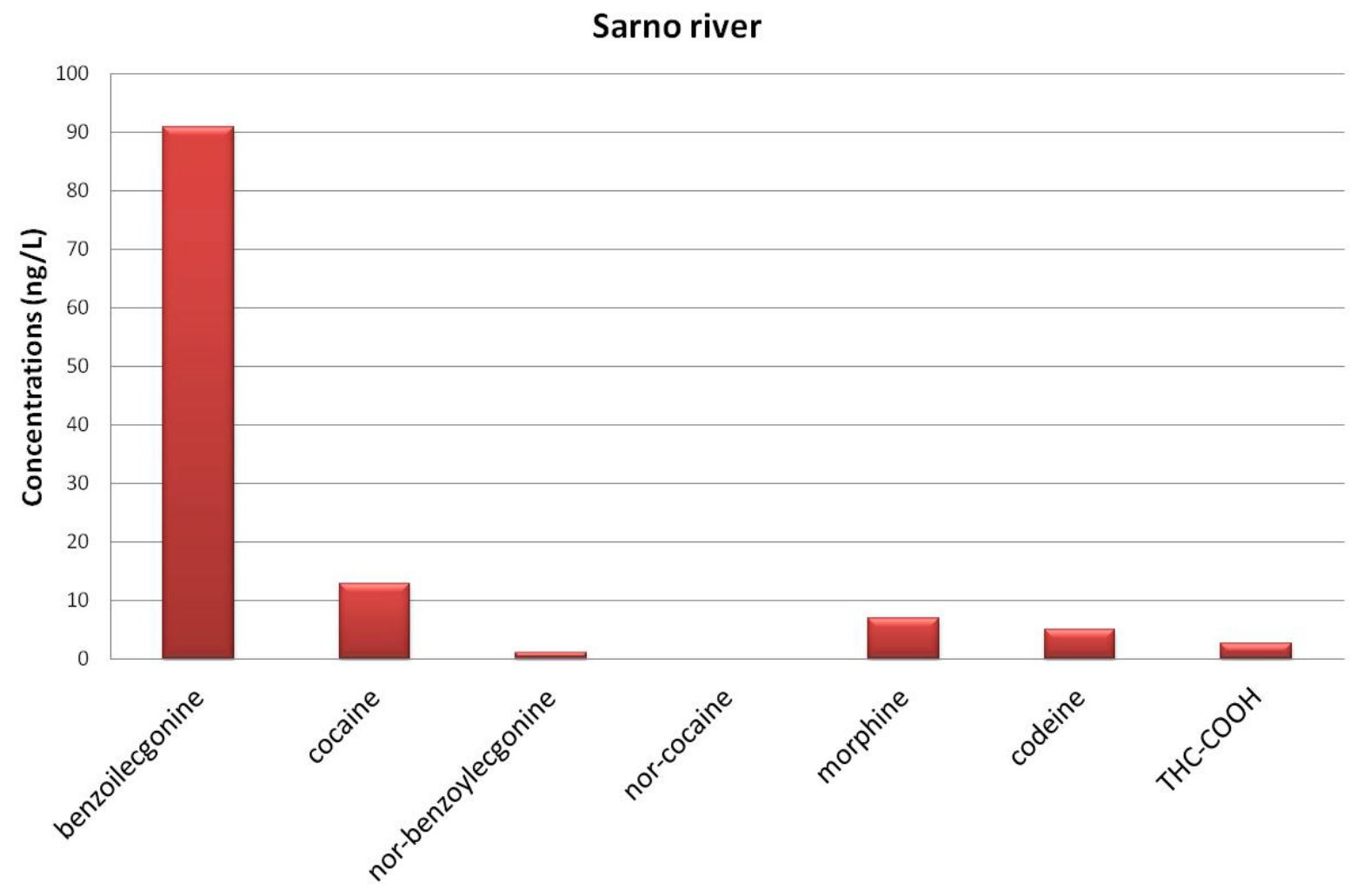

Figure 3. Illicit drug residues and main cocaine metabolites (ng/l) in the Sarno River, at the hydrographic station of Scafati (Naples, Italy). Cocaine was the most abundant illicit drug. Among cocaine metabolites, benzoylecgonine was the most abundant; nor-cocaine was undetectable. ${ }^{\mathrm{a}}$ Values significantly $(\mathrm{P}<0.001)$ different from morphine, THC-COOH and codeine values; ${ }^{b}$ Values significantly $(\mathrm{P}<0.001)$ different from nor-benzoylecgonine and nor-cocaine values.

Cocaine (13 $\pm 2 \mathrm{ng} / \mathrm{l})$ and BE (91 $\pm 10 \mathrm{ng} / \mathrm{l}$ ) levels, found in the Sarno River, were included in the range of levels found in other rivers, as the Po (cocaine: $0.5 \pm 0.2 \mathrm{ng} / \mathrm{l}$; BE: $3.7 \pm 1.2 \mathrm{ng} / \mathrm{l}$ ), the Arno (cocaine: $1.7 \pm 1.2$ ng/l; BE: $21.8 \pm 11.9$ ng/l), the Olona (cocaine: 44 ng/l; BE: 183 ng/l), the Lambro (cocaine: 15 ng/l; BE: 50 ng/l) rivers (Italy) and the Thames River (England) (cocaine: $4 \pm 0.1 \mathrm{ng} / \mathrm{l}$; BE: $13 \pm 0.6 \mathrm{ng} / \mathrm{l}$ ) [3]. These data confirm the high degree of pollution of the Sarno River, at the present one of the most polluted rivers in Europe. Indeed, chemical (mainly heavy metals and nitrogen), organic and microbial pollutants [12] [13] [15]-[17] [21] [22] were found in this river.

The presence, in the Sarno River, of illicit drugs, indicate a new, further hazard for the health of the basin's inhabitants and aquatic ecosystem. It is well known that illicit drugs influence the central nervous system and synaptic transmission, the circulatory system, the peripheral tissues, and regulate gene expression with epigenetic mechanisms [10] [23]-[27]. Therefore, unforeseen effects on humans, that use water in the food chain, via field irrigation and animal feed [12], could be assumed. Moreover, toxic effects on the aquatic fauna, still unknown, are predictable. Indeed, it is possible that illicit drugs behave like pharmaceuticals widespread in the aquatic environment, affecting the behavior of exposed organisms [28] [29] and accumulating in fish tissues [30] [31].

\section{Conclusion}

In conclusions, we have demonstrated that the Sarno River is polluted by many illicit drugs, and their metabolites. This suggests a new, potential risk for humans, that use water in the food chain, via field irrigation and animal feed, and for the health of the aquatic fauna.

\section{Acknowledgements}

The Authors wish to express their thanks to Dr. Alberto Albano and Dr. Antonino Paroli (Data Processing Cen- 
tre of the Sarno River Basin Authority), who kindly provided the map of the Sarno River basin. We like to thank Dr. Marco Coppola and Dr. Giancarla D’Auria for their assistance in collecting water samples. Moreover, the Authors wish to thank Prof. Giancarlo Carrada for his kind advices and suggestions.

\section{References}

[1] Heberer, T. (2002) Occurrence, Fate, and Removal of Pharmaceuticals Residues in the Aquatic Environment: A Review of Recent Research Data. Toxicology Letters, 131, 5-17. http://dx.doi.org/10.1016/S0378-4274(02)00041-3

[2] Zuccato, E., Chiabrando, C., Castiglioni, S., Calamari, D., Bagnati, R., Schiarea, S. and Fanelli, R. (2005) Cocaine in Surface Waters: A New Evidence-Based Tool to Monitor Community Drug abuse. Environmental Health: A Global Access Science Source, 4, 14-21.

[3] Zuccato, E., Castiglioni, S., Bagnati, R., Chiabrando, C., Grassi, P. and Fanelli, R. (2008) Illicit Drugs, a Novel Group of Environmental Contaminants. Water Research, 42, 961-968. http://dx.doi.org/10.1016/j.watres.2007.09.010

[4] Castiglioni, S., Zuccato, E., Crisci, E., Chiabrando, C., Fanelli, R. and Bagnati, R. (2006) Identification and Measurement of Illicit Drugs and Their Metabolites in Urban Wastewater by Liquid Chromatography-Tandem Mass Spectrometry. Analytical Chemistry, 78, 8421-8429. http://dx.doi.org/10.1021/ac061095b

[5] Mari, F., Politi, L., Biggeri, A., Accetta, G., Trignano, C., Di Padua, M. and Bertol, E. (2009) Cocaine and Heroin in Waste Water Plants: A 1-Year Study in the City of Florence, Italy. Forensic Science International, 189, 88-92. http://dx.doi.org/10.1016/j.forsciint.2009.04.018

[6] Zuccato, E. and Castiglioni, S. (2009) Illicit Drugs in the Environment. Philosophical Transactions of the Royal Society A, 367, 3965-3978. http://dx.doi.org/10.1098/rsta.2009.0107

[7] Postigo, C., de Alda, M.C.L. and Barcelò, D. (2010) Drugs of Abuse and Their Metabolites in the Ebro River Basin: Occurrence in Sewage and Surface Water, Sewage Treatment Plants Removal Efficiency, and Collective Drug Usage Estimation. Environmental International, 36, 75-84. http://dx.doi.org/10.1016/j.envint.2009.10.004

[8] Daughton, C.G. (2011) Illicit Drugs: Contaminants in the Environment and Utility in Forensic Epidemiology. In: Whitacre, D.M., Ed., Reviews of Environmental Contamination and Toxicology, Springer, New York, 59-110.

[9] Boleda, M.R., Galceran, M.T. and Ventura, F. (2009) Monitoring Opiates, Cannabinoids and Their Metabolites in Wastewater, Surface Water and Finished Water in Catalonia, Spain. Water Research, 43, 1126-1136. http://dx.doi.org/10.1016/j.watres.2008.11.056

[10] Brecher, E.M. (1972) Licit and Illicit Drugs. The Consumers Union Report on Narcotics, Stimulants, Depressants, Inhalants, Halluncinogens, and Marijuana-Including Caffeine, Nicotine, and Alcohol. Little, Brown and Company, Boston.

[11] Rehm, J., Taylor, B. and Room, R. (2006) Global Burden of Disease from Alcohol, Illicit Drugs and Tobacco. Drugs and Alcohol Review, 25, 503-513. http://dx.doi.org/10.1080/09595230600944453

[12] De Pippo, T., Donadio, C., Guida, M. and Petrosino, C. (2006) The Case of Sarno River (Southern Italy). Effects of Geomorphology on the Environmental Impacts. Environmental Science \& Pollution Research, 13, 184-191. http://dx.doi.org/10.1065/espr2005.08.287

[13] Melluso, G., Esposito, A., Guida, M., Maurano, F., Trieff, N.M. and Pagano, G. (1994) Distribution of Inorganic and Organic Pollutants in River Sediments in Campania, Italy. Bulletin of Environmental Contamination and Toxicology, 52, 13-18. http://dx.doi.org/10.1007/BF00197351

[14] Arienzo, M., Adamo, P., Bianco, M.R. and Violante, P. (2001) Impact of Land Use and Urban Runoff on the Contamination of the Sarno River Basin in Southwestern Italy. Water, Air \& Soil Pollution, 131, 349-366. http://dx.doi.org/10.1023/A:1011908019933

[15] Russo, C., Rocco, L., Morescalchi, M.A. and Stingo, V. (2004) Assessment of Environmental Stress by the Micronucleus Test and the Comet Assay on the Genome of Teleost Populations from Two Natural Environments. Ecotoxicology and Environmental Safety, 57, 168-174. http://dx.doi.org/10.1016/S0147-6513(03)00027-7

[16] Motta, O., Capunzo, M., De Caro, F., Brunetti, L., Santoro, E., Farina, O. and Proto, A. (2008) New Approach for Evaluating the Public Health Risk of Living near a Polluted River. Journal of Preventive Medicine and Hygiene, 49, 79-88.

[17] Vigliotta, G., Motta, O., Guarino, F., Iannece, P. and Proto, A. (2010) Assessment of Perchlorate-Reducing Bacteria in a Highly Polluted River. International Journal of Hygiene and Environmental Health, 213, 437-443. http://dx.doi.org/10.1016/j.ijheh.2010.08.001

[18] Rome-Central Directorate for Anti-Drug Services (2009) Annual Report 2009 by the Central Directorate for Anti-Drug Services of the Ministry of the Interior. http://www.interno.gov.it/mininterno/export/sites/default/it/sezioni/sala_stampa/documenti/droga/0094_2010_05_16 
Relazione_antidroga_PS_2009.html_8783074.html www.interno.gov.it/mininterno/report antidroga/2009

[19] Baselt, R.C. (1982) Disposition of Toxic Drugs and Chemicals in Man. 7th Edition, Biomedical Publications, California.

[20] Macchia, T. and Gentili, S. (2006) The Laboratory Diagnosis: Technical Aspects. In: Cocaine: Manual Update Technical Sciences cap. 4, President Council of Ministers, Rome, 217-244. http://www.dronet.org/pdf/4.2\%20Cocaina.pdf

[21] Adam, N., d’Alise, C., Parrella, P., D’Antonio, G., Del Gaizo, S., Onorato, G., Russo, R. and Scala, F. (2009) Report on the State of Campania in 2009. Chapter 7, Campania Region, Arpac, 157-175. www.arpacampania.it/

[22] Vörösmarty, C.J., McIntyre, P.B., Gessner, M.O., Dudgeon, D., Prusevich, A., Green, P., Glidden, S., Bunn, S.E., Sullivan, C.A., Reidy Liermann, C. and Davies, P.M. (2010) Global Threats to Human Water Security and River Biodiversity. Nature, 467, 555-561. http://dx.doi.org/10.1038/nature09440

[23] Nestler, E.J. (1992) Molecular Mechanisms of Drug Addiction. Journal of Neuroscience, 12, 2439-2450.

[24] Nestler, E.J. and Malenka, R.C. (2004) The Addicted Brain. Scientific American, 290, 78-85. http://dx.doi.org/10.1038/scientificamerican0304-78

[25] Zaheer Khan, M. and Law, F.C.P. (2005) Adverse Effects of Pesticides and Related Chemicals on Enzyme and Hormone Systems of Fish, Amphibians and Reptiles: A Review. Proceedings of the Pakistan Academy of Sciences, 42, 315-323.

[26] Newton, S.S. and Duman, R.S. (2006) Chromatin Remodeling: A Novel Mechanism of Psychotropic Drug Action. Molecular Pharmacology, 70, 440-443. http://dx.doi.org/10.1124/mol.106.027078

[27] Renthal, W. and Nestler, E.J. (2008) Epigenetic Mechanisms in Drug Addiction. Trends in Molecular Medicine, 14, 341-350. http://dx.doi.org/10.1016/j.molmed.2008.06.004

[28] Painter, M.M., Buerkley, M.A., Julius, M.L., Vajda, A.M., Norris, D.O., Barber, L.B., Furlong, E.T., Schultz, M.M. and Schoenfuss, H.L. (2009) Antidepressants at Environmentally Relevant Concentrations Affect Predator Avoidance Behavior of Larval Fathead Minnows (Pimephales promelas). Environmental Toxicology \& Chemistry, 28, $2677-2684$. http://dx.doi.org/10.1897/08-556.1

[29] Guler, Y. and Ford, A.T. (2010) Anti-Depressants Make Amphipods See the Light. Aquatic Toxicology, 99, $397-404$. http://dx.doi.org/10.1016/j.aquatox.2010.05.019

[30] Schultz, M.M., Furlong, E.T., Kolpin, D.W., Werner, S.L., Schoenfuss, H.L., Barber, L.B., Blazer, V.S., Norris, D.O. and Vajda, A.M. (2010) Antidepressant Pharmaceuticals in Two US Effluent-Impacted Streams: Occurrence and Fate in Water and Sediment, and Selective Uptake in Fish Neural Tissue. Environmental Science \& Technology, 44, 19181925. http://dx.doi.org/10.1021/es9022706

[31] Schultz, M.M., Painter, M.M., Bartell, S.E., Logue, A., Furlong, E.T., Werner, S.L. and Schoenfuss, H.L. (2011) Selective Uptake and Biological Consequences of Environmentally Relevant Antidepressant Pharmaceutical Exposures on Male Fathead Minnows. Aquatic Toxicology, 104, 38-47. http://dx.doi.org/10.1016/j.aquatox.2011.03.011

\section{Abbreviation List}

11-nor-9-carboxy-delta9-tetrahydrocannabinol (THC-COOH); benzoylecgonine (BE); internal standards (IS); high-pressure liquid chromatography-tandem mass spectrometry (HPLC-MS/MS); one-way analysis of variance (ANOVA) 
Scientific Research Publishing (SCIRP) is one of the largest Open Access journal publishers. It is currently publishing more than 200 open access, online, peer-reviewed journals covering a wide range of academic disciplines. SCIRP serves the worldwide academic communities and contributes to the progress and application of science with its publication.

Other selected journals from SCIRP are listed as below. Submit your manuscript to us via either submit@scirp.org or Online Submission Portal.
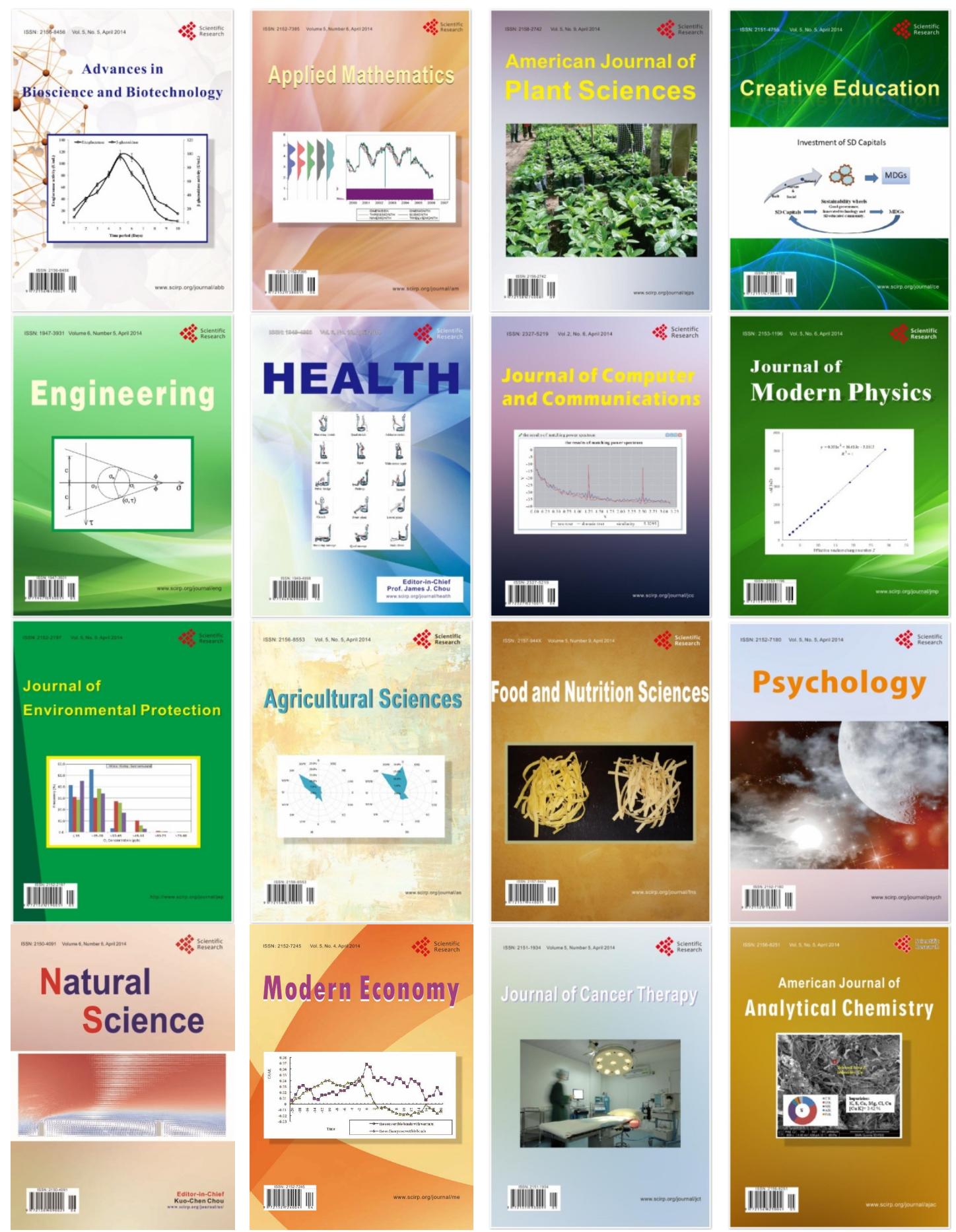